\title{
Gender Confirmation Surgery
}

Editors

LOREN S. SCHECHTER

BAUBACK SAFA

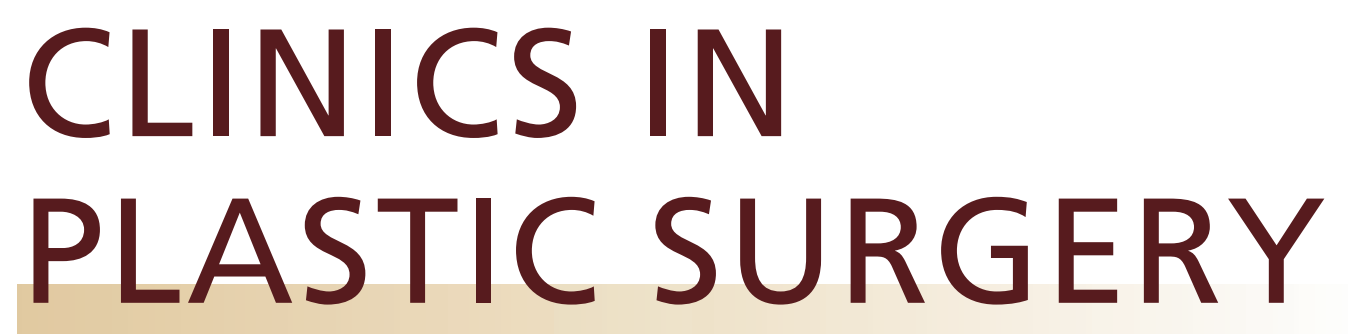

www.plasticsurgery.theclinics.com

July 2018 • Volume 45 • Number 3 